\title{
Importance of the GluN2B carboxy-terminal domain for enhancement of social memories
}

\author{
Stephanie Jacobs, ${ }^{1}$ Wei Wei, ${ }^{2}$ Deheng Wang, ${ }^{2}$ and Joe Z. Tsien ${ }^{1}$ \\ ${ }^{1}$ Department of Neurology, Brain and Behavior Discovery Institute, Medical College of Georgia, Georgia Regents University, \\ Augusta, Georgia 30907, USA; ${ }^{2}$ Banna Biomedical Research Institute, Xi-Shuang-Ban-Na Prefecture, Yunnan Province, 666100, China
}

\begin{abstract}
The $\mathrm{N}$-methyl-D-aspartate (NMDA) receptor is known to be necessary for many forms of learning and memory, including social recognition memory. Additionally, the GluN2 subunits are known to modulate multiple forms of memory, with a high GluN2A:GluN2B ratio leading to impairments in long-term memory, while a low GluN2A:GluN2B ratio enhances some forms of long-term memory. Here, we investigate the molecular motif responsible for the differences in social recognition memory and olfactory memory in the forebrain-specific transgenic GluN2A overexpression mice and the forebrainspecific transgenic GluN2B overexpression mice by using two transgenic mouse lines that overexpress chimeric GluN2 subunits. The transgenic chimeric GluN2 subunit mice were tested for their ability to learn and remember fruit scents, male juveniles of the same strain, females of the same strain, male juveniles of another strain, and rodents of another species. The data presented here demonstrate that the GluN2B carboxy-terminal domain is necessary for enhanced social recognition memory in GluN2B transgenic overexpression mice. Furthermore, the GluN2A carboxy-terminal domain is responsible for the impaired long-term olfactory and social memory observed in the GluN2A overexpression mice.
\end{abstract}

The $N$-methyl-D-aspartate (NMDA) receptor is known to play a crucial role in multiple forms of learning and memory including object recognition memory, emotional memory, social memory, extinction memory, and spatial memory (McHugh et al. 1996; Tonegawa et al. 1996; Tsien et al. 1996; Rampon et al. 2000a,b; Szapiro et al. 2003; Cui et al. 2004, 2005; Li and Tsien 2009; Wang et al. 2009; Kuang et al. 2010; Zimmerman and Maren 2010; Mei et al. 2011; Zhang et al. 2013).

NMDA receptors have been shown to be necessary for social memory in mice. Direct evidence of this was found in a post-natal deletion of GluN1 in which the knockout animals were unable to remember the stimulus partner for even a short amount of time in a habituation-dishabituation paradigm (Belforte et al. 2010). Further, Gao et al. (2009) found that both short- and long-term social recognition memory were impaired in mice treated with the NMDA antagonist ketamine. Similarly, MK-801 administration also impaired social recognition memory (van der Staay et al. 2011). Intriguingly, systemic NMDA administration was found to improve social recognition memory in rats, leading to further evidence for the importance of the NMDA receptor in social memory (Hlinak and Krejci 2002).

Remarkably, many forms of learning and memory including those listed above have been found to be modulated by the GluN2A:GluN2B subunit ratio (Buller et al. 1994; Tang et al. 1999, 2001; Philpot et al. 2001; White and Youngentob 2004; Walker and Davis 2008; Brigman et al. 2010; Cui et al. 2011, 2013; Jacobs and Tsien 2012). This ratio is dynamically regulated with the GluN2B subunit being expressed at birth and decreasing with age; while the GluN2A subunit begins to be expressed after birth and increases with age (Hestrin 1992b; Monyer et al. 1994; Sheng et al. 1994).

Increasing the GluN2B:GluN2A subunit ratio, by genetically overexpressing the GluN2B subunit in the forebrain regions, has been found to increase object recognition memory, spatial memory, working memory, and emotional memory in young and aged

\section{Corresponding author: jtsien@gru.edu}

Article is online at http://www.learnmem.org/cgi/doi/10.1101//m.038521.115. animals in multiple mammalian species (Tang et al. 1999, 2001; Philpot et al. 2001; White and Youngentob 2004; Cao et al. 2007; Wang et al. 2009; Cui et al. 2011). Conversely, decreasing the GluN2B:GluN2A subunit ratio, by genetically overexpressing the GluN2A subunit, significantly impairs long-term object recognition memory, long-term emotional memory, and spatial memory (Cui et al. 2013). Recently, it was demonstrated that the modulation of the GluN2 subunit composition in the NMDA receptor complex also modulated olfactory memory, and social recognition memory (White and Youngentob 2004; Jacobs and Tsien 2012, 2014). Interestingly, genetically increasing the GluN2B:GluN2A subunit ratio increases the ability for the transgenic GluN2B overexpression mice to learn and remember mice of another strain and animals of another rodent species (Jacobs and Tsien 2012). Remarkably, decreasing the GluN2B:GluN2A subunit ratio significantly impairs long-term social recognition memory of conspecifics, females, mice of another strain and rodents of another species (Jacobs and Tsien 2014).

Although it is known that an increased GluN2B:GluN2A subunit ratio results in increased object recognition memory, emotional memory, social memory, and spatial memory, little is known about the exact molecular mechanism responsible for this enhancement. It is of great interest to determine if the enhanced memory in the GluN2B transgenic animals is a result of the amino-terminal domain or the carboxy-terminal domain function. While GluN2 knockout models provide a platform for identifying the contribution for individual subunits by eliminating the unit completely (Ikeda et al. 1995; Sakimura et al. 1995; Kutsuwada et al. 1996; Hillman et al. 2011), a complete GluN2B knockout is perinatally lethal, thereby preventing analysis of the adult brain functions (Kutsuwada et al. 1996). Open channel blockers and antagonists act on the receptor complex which

(C) 2015 Jacobs et al. This article is distributed exclusively by Cold Spring Harbor Laboratory Press for the first 12 months after the full-issue publication date (see http://learnmem.cshlp.org/site/misc/terms.xhtml). After 12 months, it is available under a Creative Commons License (AttributionNonCommercial 4.0 International), as described at http://creativecommons. org/licenses/by-nc/4.0/. 
does not allow for the separation of the amino-terminal and membrane domain functions from the carboxy-terminal domain functions (Albensi and Ilkanich 2004; Wyllie et al. 2013; Vyklicky et al. 2014). Approaches to make chimeric subunits provide an alternative means to assess how the amino terminus and carboxy terminus would contribute to memory enhancement or impairment. Recently, it was determined, using transgenic mice overexpressing GluN2 chimeric subunits, that the GluN2B carboxyterminal domain was necessary for the enhanced object recognition memory, long-term emotional memory and extinction memory observed in the transgenic GluN2B overexpression mice regardless of whether it was coupled to the GluN2B or GluN2A amino-terminal domains (Jacobs et al. 2014). On the other hand, the GluN2A carboxy-terminus would impair long-term memory when it was coupled to the GluN2B aminoterminal domain.

While social memory is highly important for survival, it has been much less studied using genetic approaches. It is often thought that social recognition memory may involve different mechanisms than other types of memory (van der Kooij and Sandi 2012; Olson et al. 2013). In this study, we investigated the molecular mechanisms responsible for the enhanced social recognition memory seen in the GluN2B transgenic overexpression mice, as well as the long-term memory impairments observed in the transgenic GluN2A overexpression mice, by using transgenic mouse lines which overexpress chimeric GluN2 receptors. In one of the chimeric mouse lines the GluN2A amino-terminal and membrane domain is paired with the GluN2B carboxy-terminal domain (hereafter referred to as the GluN2A $2 \mathrm{~B}(\mathrm{CTD})$ mice). The second chimeric mouse line overexpresses chimeric GluN2 receptors with the GluN2B amino-terminal and membrane domain with the GluN2A carboxy-terminal domain (hereafter referred to as the GluN2B ${ }^{2 A(C T D)}$ mice). Both lines have expression of the chimeric subunits targeted to the forebrain areas. We tested the ability of the chimeric mice to learn and remember nonsocial olfactory (fruit) scents, male juvenile conspecifics, female conspecifics, mice of a different strain, and rodents of a different species, the rat.

\section{Results}

\section{Nonsocial olfactory recognition}

Because of the importance of olfaction in social recognition, we first tested the transgenic mice in an olfactory recognition task. This testing paradigm was similar to the social recognition paradigms in that one scent is presented at each trial. In the training session for the 1-h retention experiment, all groups of mice tested displayed similar investigation times of the scent (GluN2A ${ }^{2 \mathrm{~B}(\mathrm{CTD})}$ : $n=12,47.28 \pm 7.03 \mathrm{sec} ;$ GluN2 ${ }^{2 \mathrm{~A}(\mathrm{CTD})}: n=18,57.01 \pm 3.32 \mathrm{sec}$; Wt: $n=16,63.79 \pm 10.41 \mathrm{sec}$; Fig. $1 \mathrm{~A})$. After training the mice were split into two groups, one cohort was given the identical scent as in the training session (familiar scent), the second cohort was given a novel scent at the 1 -h retention session. At the retention session all three groups of mice presented with the familiar scent showed significant reductions in the exploration times of the scent (GluN2A $\mathrm{A}^{2 \mathrm{~B}(\mathrm{CTD})}: n=6,16.82 \pm 4.08$ sec, $P \leq 0.01$; GluN2B $^{2 \mathrm{~A}(\mathrm{CTD})}: \quad n=9,26.12 \pm 7.92$ sec, $P \leq 0.01$; Wt: $n=8$, $30.61 \pm 4.17 \mathrm{sec}, P<0.05)$ indicating a memory of the scent from the training session. Interestingly, the GluN2A ${ }^{2 B(C T D)}$ mice spent significantly less time investigating the familiar scent than the wild-type mice $(P=0.04)$. As expected, the two transgenic mouse groups and their wild-type littermates did not decrease the amount of time they spent investigating the novel scent $\left(\right.$ GluN2A ${ }^{2 \mathrm{~B}(\mathrm{CTD})}: n=6,58.32 \pm 13.62$ sec; GluN2B ${ }^{2 \mathrm{~A}(\mathrm{CTD})}: n=9$, $50.28 \pm 11.57 \mathrm{sec} ; \mathrm{Wt}: n=8,56.36 \pm 16.55 \mathrm{sec})$.

We also investigated the long-term olfactory memory in our GluN2A ${ }^{2 \mathrm{~B}(\mathrm{CTD})}$ and GluN2B ${ }^{2 \mathrm{~A}(\mathrm{CTD})}$ chimeric mice. Similar to the 1-h testing, all groups of mice spent similar amounts of time exploring the scent in the training session (GluN2A ${ }^{2 \mathrm{~B}(\mathrm{CTD})}: n=12$, $48.92 \pm 5.60 \mathrm{sec} ;$ GluN2B ${ }^{2 \mathrm{~A}(\mathrm{CTD})}: n=17,54.39 \pm 5.18 \mathrm{sec} ; \mathrm{Wt}$ : $n=16,68.36 \pm 9.22 \mathrm{sec}$; Fig. $1 \mathrm{~B})$. After training, the mice were split into two cohorts, one cohort was presented with the familiar scent at the 24-h retention session; the other was presented with a novel scent. Interestingly, the GluN2B ${ }^{2 \mathrm{~A}(\mathrm{CTD})}$ mice were unable to form a strong memory of the scent and spent a similar amount of time investigating the familiar scent as they did in the training session (GluN2B ${ }^{2 \mathrm{~A}(\mathrm{CTD})}: \quad n=8,42.86 \pm 12.50$ sec, $P=0.3$ ). However the GluN2A ${ }^{2 \mathrm{~B}(\mathrm{CTD})}$ mice and the wild-type mice did significantly reduce the amount of time they spent investigating the 
familiar scent (GluN2A ${ }^{2 \mathrm{~B}(\mathrm{CTD})}: n=6,7.58 \pm 1.73 \mathrm{sec}, P \leq 0.0001$; Wt: $n=7,36.47 \pm 7.89 \mathrm{sec}, P \leq 0.05)$. Interestingly, ANOVA analysis revealed that the GluN2 $\mathrm{A}^{\overline{2} \mathrm{~B}(\mathrm{CTD})}$ mice spent significantly less time investigating the familiar scent than either the wild-type mice or the GluN2B ${ }^{2 \mathrm{~A}(\mathrm{CTD})}(P=0.03)$. When the mice were presented with a novel scent they spent similar amounts of time investigating the new scent as they did the novel scent in the training session (GluN2A ${ }^{2 \mathrm{~B}(\mathrm{CTD})}: \quad n=6, \quad 42.21 \pm 10.01 \mathrm{sec}$; GluN2B $^{2 \mathrm{A(CTD})}: n=9,45.96 \pm 4.09 \mathrm{sec} ; \mathrm{Wt}: n=9,69.24 \pm 10.25$ $\mathrm{sec})$. These data demonstrate the significantly impaired long-term olfactory memory in the GluN2B ${ }^{2 A(C T D)}$ mice.

\section{Habituation-dishabituation social memory paradigm}

To test the ability of our GluN2 $\mathrm{A}^{2 \mathrm{~B}(\mathrm{CTD})}$ and GluN2B ${ }^{2 \mathrm{~A}(\mathrm{CTD})}$ chimeric mice to remember a conspecific that they have had several short encounters with within a short period of time, we tested our mice in a social habituation-dishabituation paradigm. The GluN2 $^{2 \mathrm{~B}(\mathrm{CTD})}$ and GluN2B ${ }^{2 \mathrm{~A}(\mathrm{CTD})}$ chimeric mice and their wildtype littermates showed little differences in the habituation-dishabituation paradigm. The chimeric and wild-type mice tested spent similar amounts of time investigating the stimulus mouse in the initial exposure (GluN2A ${ }^{2 \mathrm{~B}(\mathrm{CTD})}: n=12,40.63 \pm 2.51 \mathrm{sec}$; GluN2B $^{2 \mathrm{~A}(\mathrm{CTD})}: n=11,37.07 \pm 3.23$ sec; Wt: $n=12,33.46 \pm$ $2.81 \mathrm{~s} ;$ Fig. 2). In the second exposure, all three groups spent significantly less time investigating the same juvenile in a second exposure $10 \mathrm{~min}$ after the first (GluN2A ${ }^{2 \mathrm{~B}(\mathrm{CTD})}: 28.67 \pm 3.19 \mathrm{sec}, P \leq$ 0.01 ; GluN2B ${ }^{2 \mathrm{~A}(\mathrm{CTD})}: 26.92 \pm 3.11 \mathrm{sec}, P<0.05$; Wt: $24.14 \pm 2.21$ sec, $P<0.05)$. All three groups continued to decrease the amount of time that they spent investigating the familiar mouse in the third and fourth exposures (3: GluN2A ${ }^{2 \mathrm{~B} \text { (CTD): }} 22.28 \pm$ $1.34 \mathrm{sec} ;$ GluN2B ${ }^{2 \mathrm{~A}(\mathrm{CTD})}: 17.69 \pm 0.23 \mathrm{sec} ; \mathrm{Wt}: 12.50 \pm 1.60 \mathrm{sec}$, $P \leq 0.001 ; \quad 4: \quad$ GluN2A ${ }^{2 \mathrm{~B}(\mathrm{CTD})}: \quad 10.68 \pm 1.20$ sec, $\quad P \leq 0.001$; GluN2B ${ }^{2 \mathrm{~A}(\mathrm{CTD})}: 12.88 \pm 2.78 \mathrm{sec}$; Wt: $\left.7.90 \pm 1.88 \mathrm{sec}\right)$.

As a control for fatiguing effects, a fifth trial was conducted with a novel mouse. A novel conspecific was placed into the testing cage with the subject mouse for 5 and 10 min after the fourth trial. In this trial, all groups of animals tested spent significantly more time investigating the novel mouse than they did the familiar mouse in the fourth trial (GluN2A ${ }^{2 \mathrm{~B}(\mathrm{CTD})}: 37.52 \pm 3.04 \mathrm{sec}, P \leq$

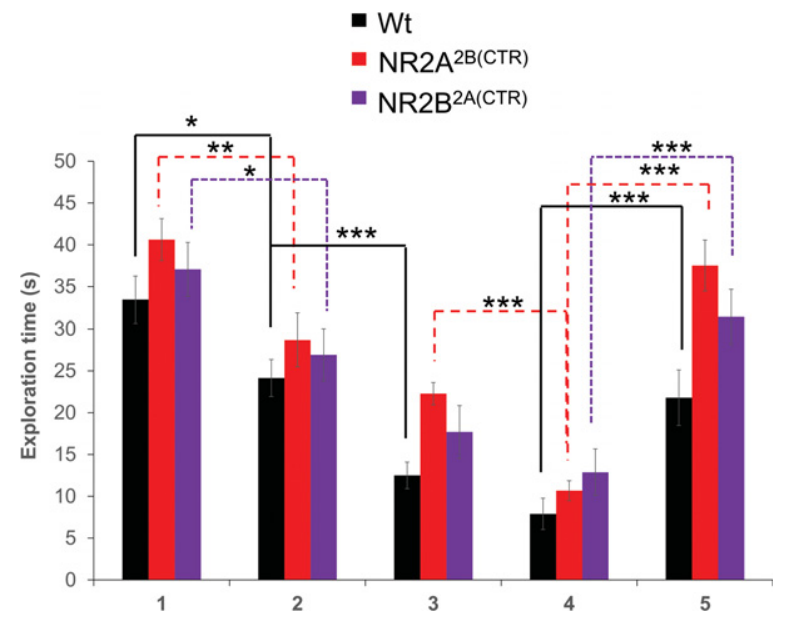

Figure 2. Both chimeric mouse lines have normal habituation-dishabituation social recognition. The GluN2A $2 B(C T D)$ mice, the GluN2B $2 A(C T D)$ mice and their wild-type littermates showed similar decreases in exploration times of the stimulus mouse when repeatedly exposed to it. Additionally, the transgenic and wild-type mice significantly increased the exploration of a novel mouse in a fifth trial. $\left({ }^{*}\right) P<0.05,\left({ }^{* *}\right) P \leq$ $0.01,\left({ }^{* *}\right) P \leq 0.001$.
0.001; GluN2B ${ }^{2 \mathrm{~A}(\mathrm{CTD})}: 31.41 \pm 3.27$ sec, $P \leq 0.001$; Wt: $21.79 \pm$ 3.32 sec, $P \leq 0.001)$.

\section{Social memory for male conspecifics}

In order to test the short- and long-term social memory for a male conspecific, we utilized a common social recognition paradigm in which a stimulus mouse is presented to the subject mouse for $5 \mathrm{~min}$. Then, at the described time either the familiar mouse is presented again or a novel mouse is presented. A significant reduction in the amount of time that the subject mouse spends investigating the familiar mouse indicates a memory of that animal.

We used two time points in our investigation, $1 \mathrm{~h}$, to test short-term memory and $24 \mathrm{~h}$, to test long-term memory. To test the short-term memory in our chimeric mice we presented a set of male subject mice with a juvenile male conspecific. In the training session for the $1 \mathrm{~h}$ memory task, all groups of mice tested spent similar amounts of time investigating the juvenile stimulus mouse (GluN2A ${ }^{2 \mathrm{~B}(\mathrm{CTD})}: n=13,114.74 \pm 9.50 \mathrm{sec}$; GluN2B ${ }^{2 \mathrm{~A}(\mathrm{CTD})}$ : $n=13,95.46 \pm 9.12 \mathrm{sec}$; Wt: $n=18,95.63 \pm 7.74 \mathrm{sec}$; Fig. $3 \mathrm{~A}$ ). After training the mice were split into two cohorts. One cohort was presented with the familiar conspecific from the training session, the second cohort was presented with a novel conspecific. The subject mice presented with a familiar conspecific spent significantly less time exploring the familiar animal in the retention session than in the training session (GluN2A $\mathrm{A}^{2 \mathrm{~B}(\mathrm{CTD})}: n=7$, $74.78 \pm 8.91 \mathrm{sec}, P \leq 0.01$; GluN2B ${ }^{2 \mathrm{~A}(\mathrm{CTD})}: n=6,53.31 \pm 10.49$ sec, $P \leq 0.01$; Wt: $n=10,62.19 \pm 9.05 \mathrm{sec}, P \leq 0.01)$. As expected, the subject mice spent similar amounts of time investigating the novel stimulus mouse as they did in the training session (GluN2A $^{2 \mathrm{~B}(\mathrm{CTD})}: n=6,115.15 \pm 10.48 \mathrm{sec}^{-}$GluN2B ${ }^{2 \mathrm{~A}(\mathrm{CTD})}: n=7$, $92.62 \pm 12.04 \mathrm{sec} ; \mathrm{Wt}: n=8,85.56 \pm 14.62 \mathrm{sec})$.

In the 24 -h test training session, all groups of mice tested spent similar amounts of time investigating the juvenile conspecific (GluN2A ${ }^{2 \mathrm{~B}(\mathrm{CTD})}: n=10,96.94 \pm 9.36$ sec; GluN2B ${ }^{2 \mathrm{~A}(\mathrm{CTD})}$ : $n=15,99.95 \pm 5.96 \mathrm{sec}$; Wt: $n=17,89.59 \pm 6.70 \mathrm{sec}$; Fig. 3B). Interestingly, when the GluN2B ${ }^{2 \mathrm{~A}(\mathrm{CTD})}$ mice were presented with a familiar conspecific, they spent nearly the same amount of time investigating the familiar conspecific in the retention session as they did in the training session (GluN2 $\mathrm{B}^{2 \mathrm{~A}(\mathrm{CTD})}: n=8$, $87.43 \pm 7.27 \mathrm{sec})$. However, both the GluN2A ${ }^{2 \mathrm{~B}(\mathrm{CTD})}$ chimeric mice and their wild-type littermates do show significant decreases in the exploration times of the familiar juvenile (GluN2A ${ }^{2 \mathrm{~B}(\mathrm{CTD})}$ : $n=5,57.23 \pm 9.36 \mathrm{sec}, P<0.05$; Wt: $n=8,46.48 \pm 7.22 \mathrm{sec}$, $P \leq 0.001)$. Interestingly, AVONA analysis revealed that the GluN2B ${ }^{2 \mathrm{~A}(\mathrm{CTD})}$ mice spent significantly more time with the familiar juvenile then did either the GluN2 $\mathrm{A}^{2 \mathrm{~B}(\mathrm{CTD})}$ mice or the wildtype mice $(P \leq 0.01)$. As expected, all groups of mice displayed similar exploration times with a novel juvenile $24 \mathrm{~h}$ after the training session (GluN2A ${ }^{2 \mathrm{~B}(\mathrm{CTD})}: n=5,111.28 \pm 7.08 \mathrm{sec}$; GluN2B $^{2 \mathrm{~A}(\mathrm{CTD})}: n=7,97.50 \pm 12.02 \mathrm{sec} ; \mathrm{Wt}: n=9,86.80 \pm$ $11.59 \mathrm{sec})$. These data indicate that the GluN2B ${ }^{2 \mathrm{~A}(\mathrm{CTD})}$ chimeric mice are unable to form a long-term memory of the male conspecific, while the GluN2A $\mathrm{A}^{2 \mathrm{~B}(\mathrm{CTD})}$ chimeric mice and their wild-type littermates can form strong memories of a juvenile male conspecific, that can last at least $24 \mathrm{~h}$.

\section{Social memory for female conspecifics}

We also investigated the ability of our transgenic GluN2A $2 \mathrm{~B}$ (CTD) and GluN2 $\mathrm{B}^{2 \mathrm{~A}(\mathrm{CTD})}$ chimeric overexpression mice and their wild-type littermates to remember and recall a female conspecific. To prevent mating behaviors, the female mouse was placed in a wire mesh enclosure. As with the male conspecifics, both short- and long-term memory durations were tested. In the training session for the 1-h memory test, all groups of mice spent 


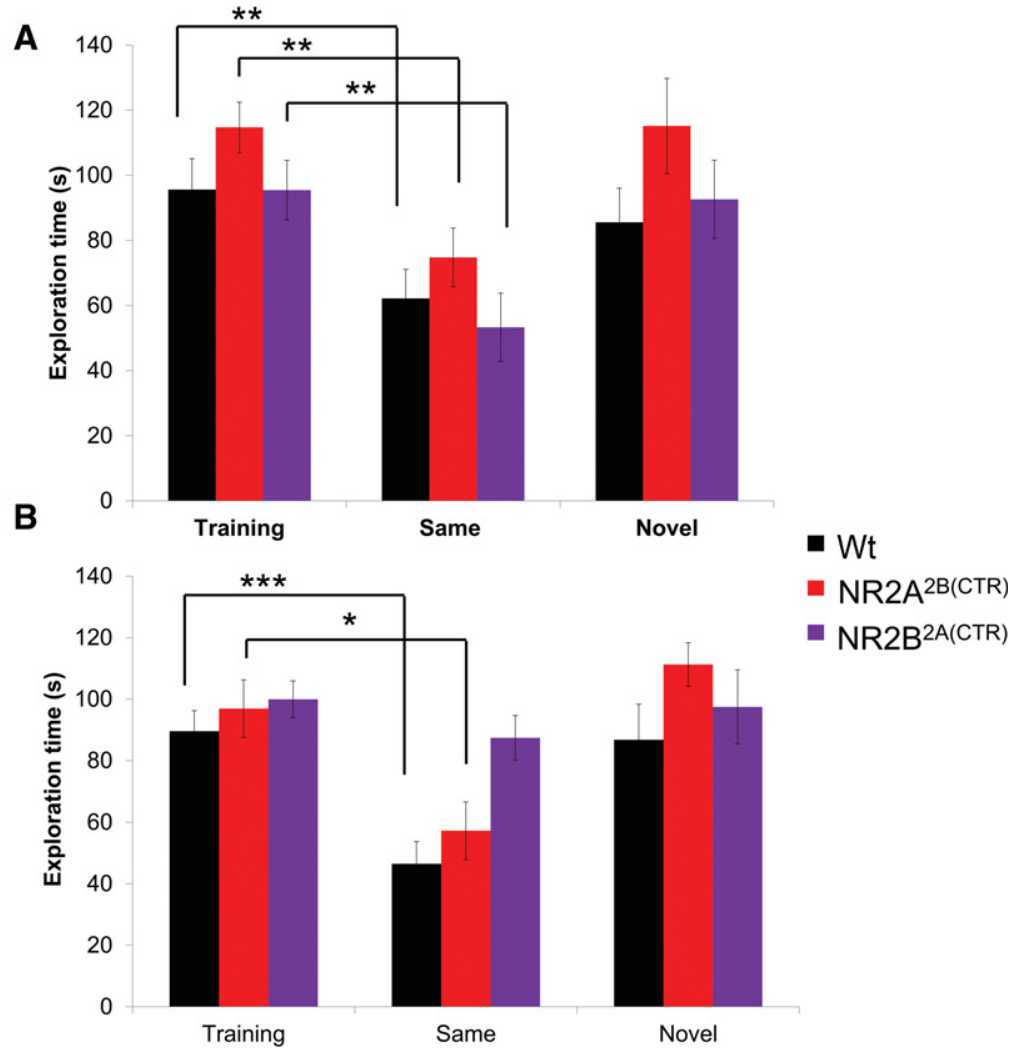

Figure 3. GluN2B $2 \mathrm{A(CTD)}$ mice are impaired in long-term social recognition of a male conspecific. $(A)$ All three groups of mice tested significantly decreased the exploration of the familiar juvenile male in the 1-h retention session. $(B)$ The GluN2B ${ }^{2 A(C T D)}$ mice were unable to recall the familiar juvenile after $24 \mathrm{~h}$ and spent a similar amount of time investigating the familiar juvenile as in the training session, whereas the GluN2 $\mathrm{A}^{2 \mathrm{~B}(\mathrm{CTD})}$ and wild-type mice spent significantly less time investigating the familiar male conspecific. $\left({ }^{*}\right) P<0.05,\left({ }^{* *}\right) P \leq 0.01,\left({ }^{* *}\right) P \leq 0.001$

similar amounts of time investigating the female conspecific (GluN2A $^{2 \mathrm{~B}(\mathrm{CTD})}: n=19,136.82 \pm 9.95 \mathrm{sec} ; \mathrm{GluN}^{2 \mathrm{~B}}{ }^{2 \mathrm{~A}(\mathrm{CTD})}: n=$ $16,164.59 \pm 7.54 \mathrm{sec}$; Wt: $n=18,168.02 \pm 10.00$ sec; Fig. $4 \mathrm{~A})$. Not surprisingly, all of the groups tested spent significantly less time investigating the familiar female conspecific after $1 \mathrm{~h}$ (GluN2A ${ }^{2 \mathrm{~B}(\mathrm{CTD})}: \quad n=10, \quad 51.30 \pm 9.26 \mathrm{sec}, \quad P \leq 0.001$; GluN2B $^{2 \mathrm{~A}(\mathrm{CTD})}: n=8,31.08 \pm 3.01 \mathrm{sec}, P \leq 0.001 ; \mathrm{Wt}: n=9$, $74.43 \pm 15.05 \mathrm{sec}, P \leq 0.001)$. Further, when a second cohort of GluN2A ${ }^{2 \mathrm{~B}(\mathrm{CTD})}$ and GluN2B ${ }^{2 \mathrm{~A}(\mathrm{CTD})}$ transgenic mice and their wild-type littermates were presented with a second novel female, they spent similar amounts of time investigating the novel female in the retention session as they did the stimulus mouse in the training session (GluN2A ${ }^{2 \mathrm{~B}(\mathrm{CTD})}: n=9,157.51 \pm 11.55 \mathrm{sec}$; GluN2B $^{2 \mathrm{~A}(\mathrm{CTD})}: n=8,151.29 \pm 12.70 \mathrm{sec} ; \mathrm{Wt}: n=9,156.66 \pm$ $6.98 \mathrm{sec})$.

We also investigated the ability of our GluN2 chimeric transgenic mice to remember a female conspecific for $24 \mathrm{~h}$. During the training session, all groups of mice spent similar amounts of time investigating the female conspecific (GluN2A ${ }^{2 \mathrm{~B}(\mathrm{CTD})}: n=$ $16,170.70 \pm 8.83 \mathrm{sec} ; \mathrm{GluN}^{2 \mathrm{~B}}{ }^{2 \mathrm{~A}(\mathrm{CTD})}: n=14,149.30 \pm 4.57 \mathrm{sec}$; Wt: $n=19,177.28 \pm 6.92 \mathrm{sec}$; Fig. 4B). Surprisingly, after $24 \mathrm{~h}$ when the GluN2B ${ }^{2 \mathrm{~A}(\mathrm{CTD})}$ transgenic mice were presented with the familiar mouse from the training session, they showed no significant decreases in the investigation times of the stimulus female mouse (GluN2B ${ }^{2 \mathrm{~A}(\mathrm{CTD})}: n=7,126.16 \pm 14.70 \mathrm{sec}$ ). However, the GluN2 $\mathrm{A}^{2 \mathrm{~B}(\mathrm{CTD})}$ mice and the wild-type mice were able to recall the female conspecific after $24 \mathrm{~h}$ and showed significant reductions in the investigation times of the familiar female $\left(\right.$ GluN2A ${ }^{2 \mathrm{~B}(\mathrm{CTD})}: n=8,64.34 \pm 9.39 \mathrm{sec}$, $P \leq 0.001$; Wt: $n=10,62.97 \pm 6.39 \mathrm{sec}$, $P \leq 0.001)$. Interestingly, AVONA analysis revealed that the GluN2B $\mathrm{B}^{2 \mathrm{~A}(\mathrm{CTD})}$ mice spent significantly more time with the familiar female than did either the GluN2A $2 \mathrm{~B}(\mathrm{CTD})$ mice or the wild-type mice $(P \leq 0.001)$. As expected, all of the mice tested spent similar amounts of time investigating the second novel female mouse (GluN2A ${ }^{2 \mathrm{~B}(\mathrm{CTD})}: n=8$, $164.71 \pm 6.00$ sec; GluN2B ${ }^{2 \mathrm{~A}(\mathrm{CTD})}: n=7$, $170.00 \pm 7.67 \mathrm{sec} ; \mathrm{Wt}: n=9,174.38 \pm$ $6.41 \mathrm{sec})$.

\section{Social recognition across mouse strains}

Animals in the wild may encounter other strains of their species and may compete with them for housing and food (Groning and Hochkirch 2008; Ord and Stamps 2009). In order to preserve their own colony and strain, mice are more likely to mate within their strain (Macbeth et al. 2009). In order to determine the ability of our transgenic mice to form a memory of a mouse of another strain, we tested the animals in a short-term $(1 \mathrm{~h})$ and long-term $(24 \mathrm{~h})$ social recognition task using white BALB/c juvenile male mice as the stimulus.

In the training session for the $1-\mathrm{h}$ memory test, all groups of mice spent approximately the same amount of time investigating the white juvenile male (GluN2A ${ }^{2 \mathrm{~B}(\mathrm{CTD})}: \quad n=12, \quad 141.29 \pm 9.47$ sec; GluN2B ${ }^{2 \mathrm{~A}(\mathrm{CTD})}: \quad n=15,128.68 \pm$ 7.70 sec; Wt: $n=13,150.35 \pm 7.72$ sec, Fig. 5A). The GluN2A $^{2 \mathrm{~B}(\mathrm{CTD})}$ mice, GluN2B ${ }^{2 \mathrm{~A}(\mathrm{CTD})}$ mice, and their wild-type littermates were able to form a short-term memory of the white $\mathrm{BALB} / \mathrm{c}$ mice, showing significant reductions in the exploration times in the $1 \mathrm{~h}$ retention session (GluN2A $\mathrm{A}^{2 \mathrm{~B}(\mathrm{CTD})}: n=6$, $44.30 \pm 8.51 \mathrm{sec}, P \leq 0.001 ;$ GluN2B ${ }^{2 \mathrm{~A}(\mathrm{CTD})}: n=8,77.51 \pm 17.08$ sec, $P \leq 0.01$; Wt: $n=6,43.86 \pm 7.10$ sec, $P \leq 0.001)$. When presented with a novel mouse after $1 \mathrm{~h}$, the second cohort of mice showed no decrease in their investigation times of the novel stimulus mouse (GluN2A ${ }^{2 \mathrm{~B}(\mathrm{CTD})}: n=6,125.23 \pm 9.13 \mathrm{sec}$; GluN2B $^{2 \mathrm{~A}(\mathrm{CTD})}: n=7,124.24 \pm 10.08$ sec; Wt: $n=7,133.92 \pm$ $7.00 \mathrm{sec})$.

We also investigated the ability of the chimeric overexpression mice to remember a mouse of a different strain and fur color for $24 \mathrm{~h}$. In the initial training session, all three groups spent similar amounts of time exploring the BALB/C stimulus mouse (GluN2A $^{2 \mathrm{~B}(\mathrm{CTD})}: n=12,121.81 \pm 11.13 \mathrm{sec} ; \mathrm{GluN} 2 \mathrm{~B}^{2 \mathrm{~A}(\mathrm{CTD})}: n=$ $16,135.43 \pm 8.39$ sec; Wt: $n=15,138.54 \pm 9.32$ sec; Fig. $5 \mathrm{~B})$. Interestingly, at the retention session, neither the GluN2B ${ }^{2 A(C T D)}$ mice nor the wild-type mice were able to form a strong memory of the BALB/C mouse and showed no reduction in the investigation times of the stimulus mouse (GluN2B ${ }^{2 \mathrm{~A}(\mathrm{CTD})}: n=7$, $139.21 \pm 12.67 \mathrm{sec}$; Wt: $n=8,129.63 \pm 9.34 \mathrm{sec})$. Remarkably, the GluN2 $\mathrm{A}^{2 \mathrm{~B}(\mathrm{CTD})}$ mice were able to form a memory of the mouse of a different strain, having significantly less exploration times in the retention session than in the training session (GluN2 $\mathrm{A}^{2 \mathrm{~B}(\mathrm{CTD})}$ : $n=6,48.28 \pm 14.11 \mathrm{sec}, P \leq 0.01)$. Interestingly, AVONA analysis revealed that the GluN2 $\mathrm{A}^{2 \mathrm{~B}(\mathrm{CTD})}$ mice spent significantly less 


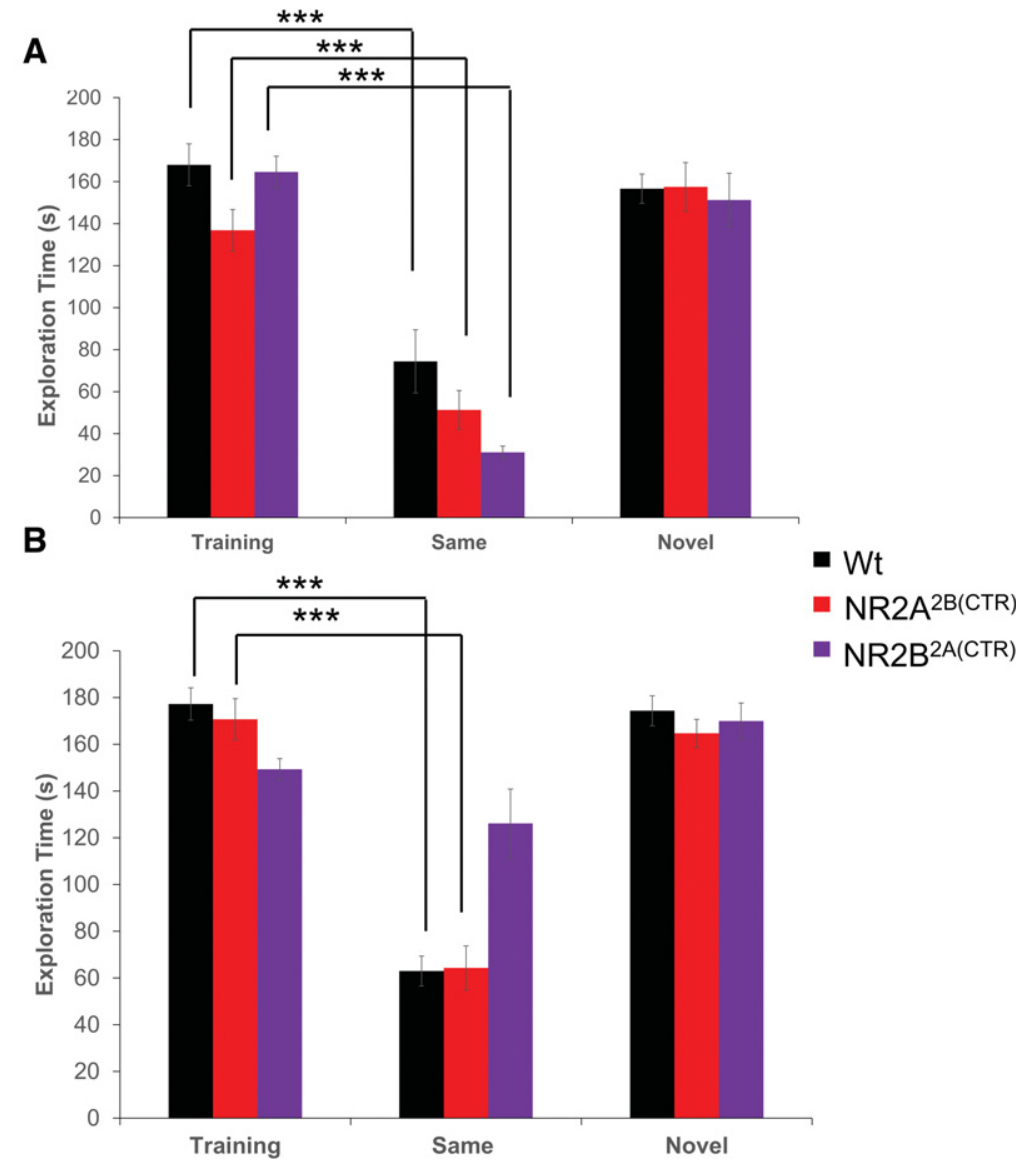

Figure 4. GluN2B $2 A(C T D)$ mice are impaired in the long-term social recognition of a female conspecific. (A) In the 1-h retention session, the three groups of mice tested were able to remember the previously presented female and spent less time investigating the female in the retention session. $(B)$ Although the GluN2A ${ }^{2 B(C T D)}$ and the wild-type mice spent significantly less time investigating the familiar female in the 24-h retention session, the GluN2B ${ }^{2 A(C T D)}$ mice were unable to form a long-term memory of the female conspecific and spent as much time exploring the female in the retention session as in the training session. $\left({ }^{*}\right) P<0.05,\left({ }^{* *}\right) P \leq 0.01,\left({ }^{* * *}\right) P \leq 0.001$.

time with the familiar cross-strain mouse than did either the GluN2B $^{2 \mathrm{~A}(\mathrm{CTD})}$ mice or the wild-type mice $(P \leq 0.001)$. As expected, when another cohort was presented with a novel BALB/c mouse the exploration times were not reduced from the initial encounter (GluN2A ${ }^{2 \mathrm{~B}(\mathrm{CTD})}: n=6,122.64 \pm 7.54 \mathrm{sec}$; GluN2B ${ }^{2 \mathrm{A(CTD})}$ : $n=9,141.79 \pm 10.70 \mathrm{sec}$; Wt: $n=7,132.51 \pm 11.94 \mathrm{sec})$. These data demonstrate that the GluN2A ${ }^{2 \mathrm{~B}(\mathrm{CTD})}$ mice have significantly improved long-term memories for a mouse of another strain.

\section{Social memory for a different rodent species}

Many species are able to recognize individuals of another species (Staples et al. 2008a,b). This allows animals to remember frequent visitors to their habitat, and potential predators (Apfelbach et al. 2005; Staples et al. 2008a,b; Okamoto and Grether 2013). For this reason, we also investigated the ability of the GluN2A $2 \mathrm{~B}$ (CTD) and GluN2 $\mathrm{B}^{2 \mathrm{~A}(\mathrm{CTD})}$ mice and their wild-type littermates to form a memory of another rodent species, the rat. To protect our transgenic mice, the rat was enclosed in a wire mesh and Plexiglas enclosure. We tested two cohorts of mice in a short- and long-term memory paradigm. In the initial training session for the short-term memory task, all three groups of mice tested spent similar amounts of time investigating the rats (GluN2A ${ }^{2 \mathrm{~B}(\mathrm{CTD})}$ : $n=13,74.99 \pm 9.38$ sec; GluN2B ${ }^{2 \text { A(CTD) }}: n=10,93.29 \pm 8.24$ sec; Wt: $n=14,96.45 \pm 15.14$ sec; Fig. $6 \mathrm{~A})$. After $1 \mathrm{~h}$, the same rat was reintroduced back into the testing cage with the mouse. Interestingly, all three groups were able to form a short-term memory of the rat as indicated by a significant decrease in the exploration times from the initial training session (GluN2A ${ }^{2 \mathrm{~B}(\mathrm{CTD})}: n=6,15.89 \pm 3.80$ sec, $P \leq 0.001 ; \quad$ GluN2B ${ }^{2 A(C T D)}: n=5$, $27.98 \pm 2.52 \mathrm{sec}, P \leq 0.001$; Wt: $n=7$, $47.35 \pm 5.70$ sec, $P<0.05)$. As expected, a second cohort of mice spent approximately the same amount of time investigating a second novel rat (GluN2A ${ }^{2 \mathrm{~B}(\mathrm{CTD})}: n=7,50.28 \pm 7.89 \mathrm{sec}$; GluN2B $^{2 \mathrm{~A}(\mathrm{CTD})}: n=5,79.19 \pm 10.07 \mathrm{sec}$; Wt: $n=7,121.57 \pm 30.24 \mathrm{sec})$.

We also tested the ability of our GluN2A $\mathrm{A}^{2 \mathrm{~B}(\mathrm{CTD})}$ and GluN2B ${ }^{2 \mathrm{~A}(\mathrm{CTD})}$ transgenic mice to form a long-term memory of another species. In the initial training session, all three groups spent similar amounts of time investigating the rats (GluN2A $^{2 \mathrm{~B}(\mathrm{CTD})}: \quad n=13, \quad 63.64 \pm 9.28$ sec; GluN2B $^{2 \mathrm{~A}(\mathrm{CTD})}: n=10,74.86 \pm 6.16$ sec; Wt: $n=16,78.19 \pm 14.90 \mathrm{sec}$; Fig. $6 \mathrm{~B})$. Interestingly, the GluN2B ${ }^{2 A(C T D)}$ mice and their wild-type littermates were unable to form a long-term memory of the rat. At the 24 -h retention session the GluN2B ${ }^{2 A(C T D)}$ mice and their wildtype littermates did not reduce the exploration times of the rat $\left(\right.$ GluN2 $\mathrm{B}^{2 \mathrm{~A}(\mathrm{CTD})}$ : $n=5, \quad 73.53 \pm 10.53$ sec; Wt: $n=7$, $91.10 \pm 13.87 \mathrm{sec})$. Surprisingly, the GluN2A ${ }^{2 B(C T D)}$ mice were able to form a long-term memory of the rat and significantly reduced the time spent investigating the rat at the $24 \mathrm{~h}$ retention session (GluN2A ${ }^{2 \mathrm{~B}(\mathrm{CTD})}: n=6,26.47 \pm 4.48 \mathrm{sec}$, $P<0.05)$. Interestingly, ANOVA analysis revealed that the GluN2A $\mathrm{A}^{2 \mathrm{~B}(\mathrm{CTD})}$ mice spent significantly less time with the familiar rat than did either the GluN2B ${ }^{2 A(C T D)}$ mice or the wild-type mice $(P \leq 0.01)$. When a second cohort of transgenic mice were introduced to a second novel rat, the mice did not reduce their investigation times from the initial training session (GluN2A ${ }^{2 \mathrm{~B}(\mathrm{CTD})}: n=7,56.61 \pm 8.41 \mathrm{sec}$; GluN2B ${ }^{2 \mathrm{~A}(\mathrm{CTD})}$ : $n=5,73.50 \pm 1.88 \mathrm{sec}$; Wt: $n=9,92.38 \pm 9.31 \mathrm{sec})$.

\section{Conclusions}

Here we have shown that the GluN2B carboxy-terminal intracellular domain is essential for enhanced social recognition memory. Transgenic mice overexpressing chimeric receptors with the GluN2A amino-terminal domain and the GluN2B carboxyterminal domain showed enhanced cross-strain and cross-species recognition, similar to the GluN2B overexpression mice previously tested (Jacobs and Tsien 2012). Additionally, transgenic mice overexpressing the chimeric subunit with the GluN2B aminoterminal domain and the GluN2A carboxy-terminal domain demonstrated impaired long-term social recognition and olfactory recognition memory, similar to what was previously described in the transgenic GluN2A overexpression mice (Jacobs and Tsien 2014). 


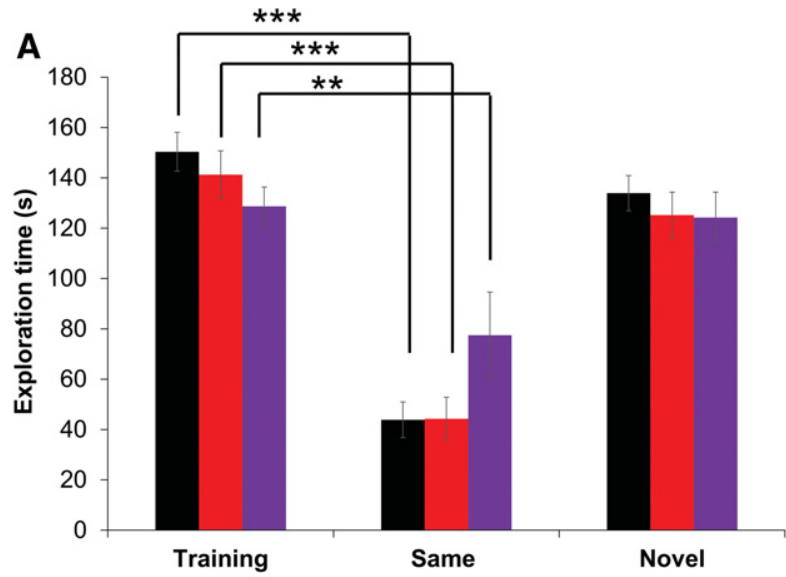

B

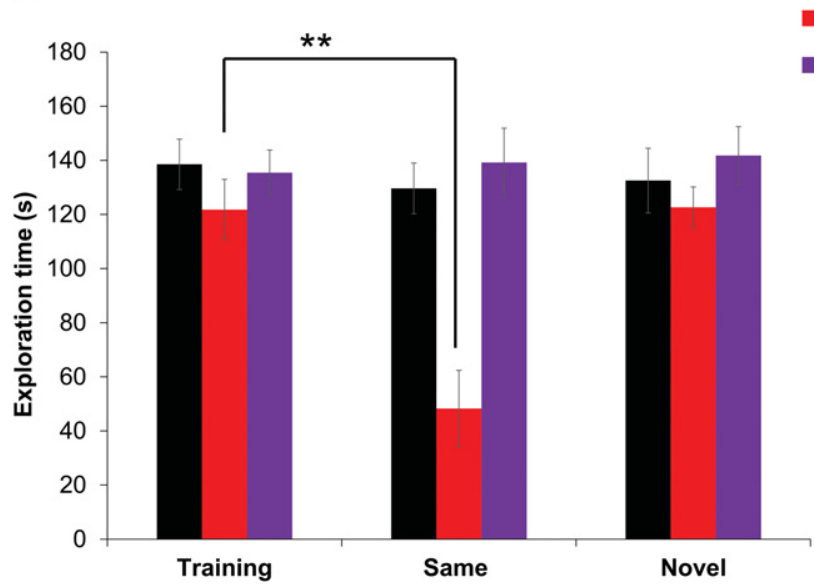

Figure 5. The GluN2A $\mathrm{A}^{2 \mathrm{~B}(\mathrm{CTD})}$ mice show enhanced long-term social recognition abilities for a mouse of another strain. $(A)$ The three groups of mice tested all spent significantly less time exploring the familiar cross-strain mouse in the 1-h retention session indicating the ability to form a short-term memory of a mouse of another strain. (B) Surprisingly, only the GluN2A ${ }^{2 B(C T D)}$ mice are able to remember the mouse of another strain after $24 \mathrm{~h}$. The GluN2B ${ }^{2 A(C T D)}$ mice and wild-type mice spent similar amounts of time exploring the familiar mouse at the $1 \mathrm{~h}$ retention session. $\left(^{*}\right) P<0.05,\left({ }^{* *}\right) P \leq$ $0.01,\left({ }^{* *}\right) P \leq 0.001$.

The NMDA receptor is highly expressed in the forebrain areas (Hestrin 1992b; Monyer et al. 1994; Sheng et al. 1994) and has been shown to be necessary in the formation of memory (Tsien et al. 1996; Gao et al. 2010; Gupta-Agarwal et al. 2014) and the consolidation of long-term memory (Shimizu et al. 2000; Santini et al. 2001; Roesler et al. 2005; Wu et al. 2007; Liu et al. 2014). While social memory is a different form of memory involving different mechanisms than olfactory memory, several of the same brain areas are involved in both types of memory. In general, there are two major olfactory subsystems, the main olfactory system and the vomeronasal system. The main olfactory system detects mainly volatile odorants and MHC molecules (Spehr et al. 2006) via the main olfactory epithelium which projects to the main olfactory bulb and the anterior olfactory nucleus. The vomeronasal system is important for the detection of nonvolatile pheromones and major histocompatibility complex (MHC) molecules (Leinders-Zufall et al. 2004) by activation of the vomeronasal epithelium which projects to the accessory olfactory bulb (Matsuo et al. 2015). The two subsystems provide complementary information when the animal is confronted by another animal. Deficits in long-term olfactory memory, such as those observed in the GluN2B ${ }^{2 \mathrm{~A}(\mathrm{CTD})}$ mice are likely to contribute to deficits in long- term social memory. Additionally, the transgene used in the GluN2B ${ }^{2 \mathrm{~A}(\mathrm{CTD})}$ mice and GluN2A ${ }^{2 \mathrm{~B}(\mathrm{CTD})}$ mice is targeted to the forebrain areas (Tang et al. 1999; Cui et al. 2013; Jacobs et al. 2014) which include the main olfactory bulb and accessory olfactory bulb as well as several downstream targets of these areas including the amygdala, hippocampus, and olfactory cortex (Sanchez-Andrade and Kendrick 2009) which will also contribute to the observed impairments in social recognition. Similarly, increased long-term olfactory memory, is also likely to contribute to enhanced social recognition observed in the GluN2A ${ }^{2 \mathrm{~B}(\mathrm{CTD})}$ mice. This enhancement is due to the increased GluN2B subunit carboxyterminal domain and intracellular signaling cascades present in these transgenic mice. Similar increases in longterm social memory have been observed in transgenic mice overexpressing the GluN2B subunit in the forebrain regions (Jacobs and Tsien 2012).

The GluN2A and GluN2B subunits are the main subunits available in excitatory synapses in the forebrain regions for receptor complex formation (Monyer et al. 1992; Sheng et al. 1994) and are ideal for coincidence detection due to their strong $\mathrm{Mg}^{2+}$ dependency (Dingledine et al. 1999; Cull-Candy and Leszkiewicz 2004; Erreger et al. 2005). Recombinant GluN2B-containing complexes in vitro display longer excitatory postsynaptic potentials than the GluN2A-containing complexes (Hestrin 1992a,b; Monyer et al. 1992). Incorporation of GluN2B into the receptor complex increases the time-window for synaptic coincidence over GluN2A diheteromeric complexes. Genetic overexpression of the GluN2B subunit in the forebrain areas indeed leads to longer channel-opening duration, as well as enhanced learning and memory (Tang et al. 1999, 2001; Philpot et al. 2001; Wang et al. 2009; Cui et al. 2011). This reinforces the idea that the NMDA receptor mediates learning and memory at the synaptic level by controlling the time-window of coincidence detection. This implies that the channel-opening duration of the NMDA receptor should be the most critical feature for optimal learning and memory.

Interestingly, biochemical studies have shown that the intracellular carboxy-terminal domains of the GluN2A and GluN2B subunits do not show sequence homology and may preferentially interact with different downstream molecules (Kennedy et al. 2005). Conversely, studies using genetically truncated GluN2 intracellular carboxy-terminal domains demonstrate that the carboxy-terminal connections are essential for receptor function (Sprengel et al. 1998). Interestingly, the phenotype of each carboxy-terminal truncated mouse very closely resembled that of a GluN2 subunit knockout mouse line. Most relevant to the present study are the GluN2 $\mathrm{B}^{\Delta \mathrm{C} / \Delta \mathrm{C}}$ and the GluN2A $\mathrm{A}^{\Delta \mathrm{C} / \Delta \mathrm{C}}$ mice. In homozygous GluN2 $\mathrm{B}^{\Delta \mathrm{C} / \Delta \mathrm{C}}$ mice, death occurred shortly after birth, as in the GluN2B ${ }^{-/-}$knockout mice, limiting a detailed analysis of physiology and behavior (Kutsuwada et al. 1996). 
A

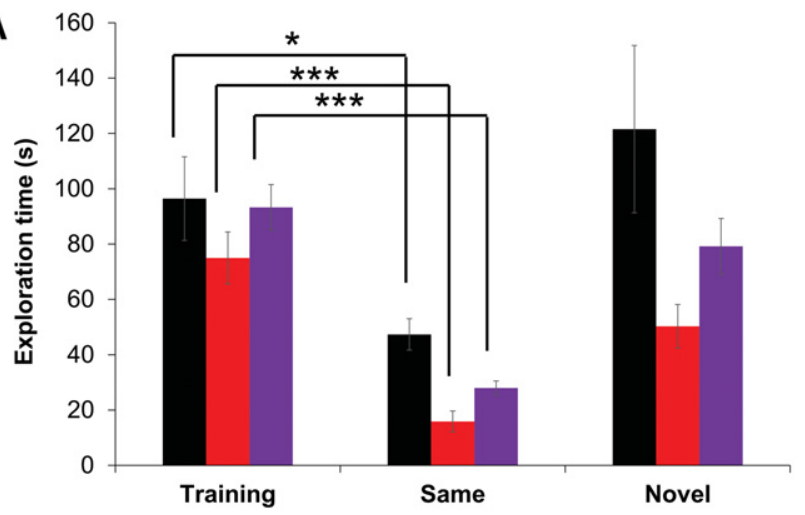

B

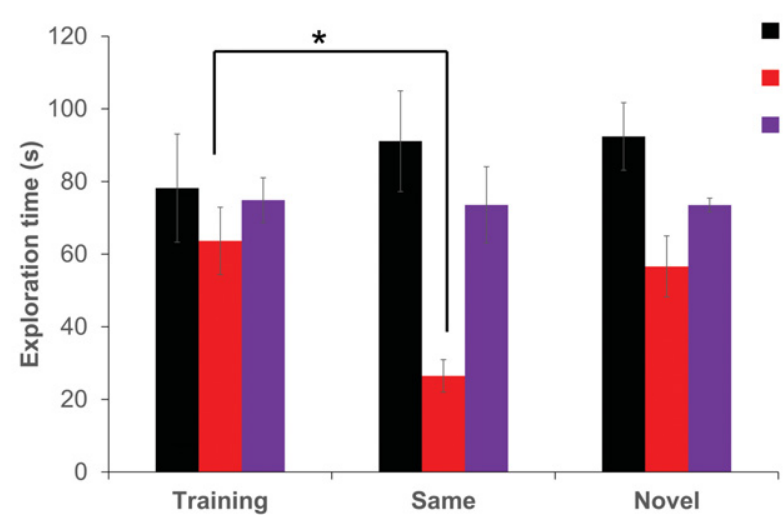

Figure 6. The GluN2A $2 \mathrm{~B}(\mathrm{CTD})$ mice have enhanced social recognition abilities for an animal of another species. (A) Both transgenic mouse groups and their wild-type littermates were able to form a shortterm memory of a different rodent species, a rat. $(B)$ In the 24-h retention session, only the GluN2A ${ }^{2 B(C T D)}$ mice were able to remember the rat from the training session while the GluN2B $2 \mathrm{~A}(\mathrm{CTD})$ and wild-type mice spent a similar amount of time investigating the rat in both sessions. $\left({ }^{*}\right) P<0.05,\left({ }^{* *}\right) P \leq 0.01,\left({ }^{* *}\right) P \leq 0.001$.

Physiological studies of GluN2B ${ }^{-/-}$knock out embryonic neocortical neurons found significantly reduced mean peak amplitude of excitatory postsynaptic currents, and reduced peak open probabilities (Mohrmann et al. 2002). Interestingly, the GluN2A $\mathrm{A}^{\Delta \mathrm{C} / \mathrm{AC}}$ mice showed impaired contextual fear conditioning and altered synaptic function. This is similar to what has been observed in GluN2A ${ }^{-/-}$knockout mice as well (Sakimura et al. 1995; Ito et al. 1996). Furthermore, carboxy-terminal truncation studies have demonstrated that the carboxy-terminal domain may have a regulatory role in gating properties (Punnakkal et al. 2012), and synaptic transmission and plasticity by controlling the open probability of the receptor (Rossi et al. 2002). In addition to intracellular signaling cascades, the carboxy-terminal domain can cause alterations in the function of the amino-terminal domain through phosphorylation by cAMP/protein kinase $\mathrm{A}$ (PKA). Multiple phosphorylation sites along the carboxy-terminal domain have been found to modulate gating and $\mathrm{Ca}^{2+}$ receptor permeability (Aman et al. 2014; Murphy et al. 2014). PKC phosphorylation is also known to modulate binding of the $\alpha$ CAMKII binding the NMDA receptor complex (Gardoni et al. 2001), as well as trafficking of the receptor complex to the synapse (Chung et al. 2004; Tang et al. 2010). These data highlight the importance of the carboxy-terminal domain of the NMDA receptor both in intracellular signaling and regulation of channel properties.

The GluN2 carboxy-terminal domains are known to interact with proteins from the postsynaptic density (PSD) family of proteins affecting synaptic localization, clustering, and signal transduction (Sheng 1996; Kennedy 1997; Kennedy and Bakay 1997; Kornau et al. 1997; Steigerwald et al. 2000). Although several truncated carboxy-terminal studies have focused on the mechanisms by which the GluN2 subunits mediate NMDA receptor function, its role in learning and memory is still undefined. In addition, modulating the GluN2 receptor subunit composition has been found to modulate social recognition memory. Interestingly, a 129P2 inbred strain of mice, in which reduced Csk expression causes an elevated GluN2B subunit expression, was found to have increased social recognition memory as well as increased memory for social food preference (Sinai et al. 2012). Directly increasing the GluN2B subunit expression by genetic overexpression also increased the social recognition memory in transgenic GluN2B overexpression mice (Jacobs and Tsien 2012). Conversely, reducing the GluN2B: GluN2A subunit ratio, by genetically overexpressing the GluN2A subunit; decreased the social recognition memory in the transgenic GluN2A overexpression mice (Jacobs and Tsien 2014). However, despite accumulating evidence suggesting the importance of the GluN2 subunits for the modulation of learning and memory, little is known as to the actual contributions of the molecular motifs of the GluN2 subunits. This is due to the innate complexity of separating the amino-terminal and membrane functions from the carboxyterminal intracellular signaling mechanisms in a single receptor complex.

It is difficult to determine how the carboxy-terminal affects the function of the receptor using current methods (i.e., subunit knockouts, carboxy-terminal truncations or pharmacological channel blockers). An alternative way to investigate the role of the carboxy-terminal domain on NMDA receptor function is to replace the carboxy-terminal cytoplasmic domain of one subunit with the carboxy-terminal domain of another subunit, such that the receptor remains functionally intact. This allowed for the amino-terminal and membrane domains to be coupled with the carboxy-terminal signaling cascade of another subunit. Recent studies using this technique have shown that, although some behaviors may be unique functions of either the GluN2A carboxy-terminal domain (i.e., locomotion and impulsivity) or the GluN2B carboxy-terminal domain (i.e., perceptual learning, anxiety, and motor learning), other behaviors may be attributed to both subunit carboxy-terminal domains (Ryan et al. 2013).

In summary, by overexpressing two different GluN2A or GluN2B chimeric receptors, we have investigated how distinct GluN2A or GluN2B molecular domains regulate several forms of social recognition memory. The behavioral data for the chimeric GluN2 $\mathrm{A}^{2 \mathrm{~B}(\mathrm{CTD})}$ mice suggest that their long-term memory parallels that of our previously produced GluN2B transgenic mice (Jacobs and Tsien 2012), while the GluN2B ${ }^{2 \mathrm{~A}(\mathrm{CTD})}$ transgenic mice performed similarly to the GluN2A transgenic mice (Jacobs and Tsien 2014). This indicates that the carboxy-terminal domain 
is the crucial domain for improved social memory function in the GluN2B transgenic mice. This provides strong neurogenetic evidence that the intracellular signaling processes controlled by the carboxy-terminal domain of the GluN2B subunit is necessary and sufficient for achieving superior social memory functions.

\section{Materials and Methods}

\section{Animals}

For all experiments, adult (3-7 months old) male transgenic GluN2 $\mathrm{A}^{2 \mathrm{~B}(\mathrm{CTD})}$ and GluN2B $\mathrm{B}^{2 \mathrm{~A}(\mathrm{CTD})}$ overexpression mice, and their wild-type littermates were generated as previously described and backcrossed to the C57BL/6J wild-type line (Jacobs et al. 2014). Genotypes of the mice were determined by PCR analysis of a tail biopsy sample using an SV-40 probe. All animals were maintained in a standard animal vivarium, group-housed (3-5 animals per cage) in standard cages, on a 12:12 h light-dark cycle under controlled temperature and humidity. Mice were housed in separate rooms from rats. All animals were allowed free access to food and water, except during experimental procedures. Behavioral testing occurred in a specially designed, noise-reduced, dimly lit animal behavior room. Protocols were approved by the Institutional Animal Care and Use Committee (IACUC) of Georgia Regents University, and are in strict adherence with the National Institutes of Health (NIH) Guide for Care and Use of Laboratory Animals.

The subject mouse was said to be exploring the stimulus when the subject mouse had its head directed toward the stimulus within 1 in of it, or was touching, smelling, or licking the face or anogenital region of the stimulus animal, or following closely behind ( $\leq 1$ in) it (Thor and Holloway 1982). Interacting pairs were closely observed during social encounters for the safety of all the animals. For male stimuli, juvenile male animals, $\sim 1$ mo of age, were used to reduce aggression of the subject mice. For testing, the subject mice were separated into individual testing cages, identical to the housing cages, $30 \mathrm{~min}$ prior to the experimental protocol for acclimation.

\section{Nonsocial olfactory recognition}

Due to the importance of olfactory abilities in social recognition, we also investigated nonsocial olfactory recognition. Fruit juices were used as the nonsocial odor. A "scent cup" was constructed from a small plastic dish with five holes drilled into the top. Mice were allowed to habituate to the empty scent cup for 10 min the day before testing. As described, the mouse was allowed to habituate to the testing cage, a standard housing home cage, for $30 \mathrm{~min}$ prior to testing. On the training day, $0.10 \mathrm{~mL}$ of lemon juice, lime juice, orange juice or pineapple juice was placed on a piece of filter paper inside the scent cup and the scent cup was sealed. The cup was placed into the testing cage. The time the mouse spent exploring the scent was recorded. At the described time, the mouse was returned to the testing cage and either the familiar scent or a novel scent was placed back into the cage for 5 min.

\section{Habituation-dishabituation social memory paradigm}

The first social memory paradigm that we used was the habituation-dishabituation paradigm (Dantzer et al. 1987; Winslow and Camacho 1995) in which the subject mouse is exposed multiple times in succession, to the stimulus juvenile C57BL/6J male mouse (1 mo of age). The reduced investigation times in subsequent exposures are a result of a short-term memory of the familiar stimulus mouse. The dishabituation phase consists of a fifth exposure session in which the subject mouse is exposed to a novel $\mathrm{C} 57 \mathrm{BL} / 6 \mathrm{~J}$ juvenile male. This trial is used as an indicator of the fatigue of the subject mouse.

To assess the habituation-dishabituation paradigm in our mice, we separated group-housed transgenic mice and their wildtype littermates into individual testing cages 30 min prior to testing. For the initial encounter, a juvenile 1-mo-old male C57BL/6J mouse was introduced into the cage of the adult male mouse for 1 min. The amount of time the adult male mouse spent exploring the juvenile was measured, using the exploration criteria stated above. After $1 \mathrm{~min}$, the juvenile mouse was removed from the testing cage and placed into a holding cage. After a 10-min delay, the juvenile mouse was placed back into the testing cage with the subject mouse for the second trial. This was repeated for a total of four trials. For the fifth trial, a novel juvenile ( $1 \mathrm{mo}$ old $) \mathrm{C} 57 \mathrm{BL} /$ $6 \mathrm{~J}$ male was introduced into the testing cage with the subject mouse for $1 \mathrm{~min}$.

\section{Social recognition memory}

In the remaining social recognition experiments, subject mice were assigned a stimulus group (i.e., juvenile male conspecific, female conspecific, cross-strain mouse, or rat). Subject mice were separated from their home cages into individual testing cages, and allowed to acclimate for $30 \mathrm{~min}$. A stimulus animal was placed into the testing cage with the subject mouse for $5 \mathrm{~min}$. The subject mice were then split into a same animal recall group or a novel animal recall group.

A significant decrease in the amount of time the subject spent exploring the familiar stimulus animal is used as the performance index for measuring social memory. In a parallel retention session, a novel animal was used as a control for reductions in exploration due to possible fatigue. Any differences in testing protocols for each stimulus group are described below.

\section{Social memory for male conspecifics}

To investigate the memory of our chimeric GluN2 mice for a male conspecific, 1-mo-old male wild-type mice, from the same lineage, were used as stimulus mice. The testing protocol was the same as described above.

\section{Social memory for female conspecifics}

We also investigated the social memory of our transgenic male mice for their female counterparts. To allow for exploration of females without mating behaviors, we placed female littermates (36 mo of age) into circular wire mesh enclosures. These enclosures allowed for the mice to interact and sniff each other, while not allowing for mounting and mating behaviors. The subject mice were allowed to habituate to the empty enclosure for 10 min the day before the testing and the day of testing, to reduce exploration as a result of a novel object. The testing protocol was the same as previously described above.

\section{Social recognition across mouse strains}

To further investigate the memory abilities of our chimeric transgenic mice, we tested their ability to remember a mouse of a different strain and color. We used juvenile white BALB/c males (6-8 wk old) as the stimulus mice. The testing protocol was the same as described above.

\section{Social memory for a different rodent species}

We also investigated the ability of our transgenic mice to form a memory of a different rodent species, the rat. To protect the subject mice from previously noted muricide by rats (Noack et al. 2010), we constructed a protective enclosure of wire mesh around the rat. The enclosure allowed for access to all four sides and the top of the rat. The mice were habituated to the empty enclosure for $10 \mathrm{~min}$ in the testing cage the day before, and the day of the training session. Long-Evans hooded rats ( 4 wk old) were used as stimulus animals. Interactions between rats and mice were closely observed for the protection of the transgenic mice. The protocol was the same as stated above.

\section{Statistical analysis}

Graphed data are mean \pm SEM. Paired Student's $t$-tests were used to analyze significance of initial exploration versus recall 
exploration. ANOVA analysis was used to evaluate differences among groups. Significance level was $P<0.05$.

\section{Acknowledgments}

We would like to express our deep gratitude to NIH (NINDS), and Yunnan Province Department of Science and Technology for the support of our work.

\section{References}

Albensi BC, Ilkanich E. 2004. Open-channel blockers of the NMDA receptor complex. Drug News Perspect 17: 557-562.

Aman TK, Maki BA, Ruffino TJ, Kasperek EM, Popescu GK. 2014. Separate intramolecular targets for protein kinase A control $N$-methyl-D-aspartate receptor gating and $\mathrm{Ca}^{2+}$ permeability. J Biol Chem 289: 18805-18817.

Apfelbach R, Blanchard CD, Blanchard RJ, Hayes RA, McGregor IS. 2005. The effects of predator odors in mammalian prey species: a review of field and laboratory studies. Neurosci Biobehav Rev 29: 1123-1144.

Belforte JE, Zsiros V, Sklar ER, Jiang Z, Yu G, Li Y, Quinlan EM, Nakazawa K. 2010. Postnatal NMDA receptor ablation in corticolimbic interneurons confers schizophrenia-like phenotypes. Nat Neurosci 13: 76-83.

Brigman JL, Wright T, Talani G, Prasad-Mulcare S, Jinde S, Seabold GK, Mathur P, Davis MI, Bock R, Gustin RM, et al. 2010. Loss of GluN2B-containing NMDA receptors in CA1 hippocampus and cortex impairs long-term depression, reduces dendritic spine density, and disrupts learning. J Neurosci 30: 4590-4600.

Buller AL, Larson HC, Schneider BE, Beaton JA, Morrisett RA, Monaghan DT. 1994. The molecular basis of NMDA receptor subtypes: native receptor diversity is predicted by subunit composition. J Neurosci 14: $5471-5484$

Cao X, Cui Z, Feng R, Tang YP, Qin Z, Mei B, Tsien JZ. 2007. Maintenance of superior learning and memory function in NR2B transgenic mice during ageing. Eur J Neurosci 25: 1815-1822.

Chung HJ, Huang YH, Lau LF, Huganir RL. 2004. Regulation of the NMDA receptor complex and trafficking by activity-dependent phosphorylation of the NR2B subunit PDZ ligand. J Neurosci 24: 10248-10259.

Cui Z, Wang H, Tan Y, Zaia KA, Zhang S, Tsien JZ. 2004. Inducible and reversible NR1 knockout reveals crucial role of the NMDA receptor in preserving remote memories in the brain. Neuron 41: 781-793.

Cui Z, Lindl KA, Mei B, Zhang S, Tsien JZ. 2005. Requirement of NMDA receptor reactivation for consolidation and storage of nondeclarative taste memory revealed by inducible NR1 knockout. Eur J Neurosci 22: $755-763$.

Cui Y, Jin J, Zhang X, Xu H, Yang L, Du D, Zeng Q, Tsien JZ, Yu H, Cao X. 2011. Forebrain NR2B overexpression facilitating the prefrontal cortex long-term potentiation and enhancing working memory function in mice. PLoS One 6: e20312.

Cui Z, Feng R, Jacobs S, Duan Y, Wang H, Cao X, Tsien JZ. 2013. Increased NR2A:NR2B ratio compresses long-term depression range and constrains long-term memory. Sci Rep 3: 1036.

Cull-Candy SG, Leszkiewicz DN. 2004. Role of distinct NMDA receptor subtypes at central synapses. SCi STKE 2004: re16.

Dantzer R, Bluthe RM, Koob GF, Le Moal M. 1987. Modulation of social memory in male rats by neurohypophyseal peptides. Psychopharmacology (Berl) 91: 363-368.

Dingledine R, Borges K, Bowie D, Traynelis SF. 1999. The glutamate receptor ion channels. Pharmacol Rev 51: 7-61.

Erreger K, Dravid SM, Banke TG, Wyllie DJ, Traynelis SF. 2005. Subunit-specific gating controls rat NR1/NR2A and NR1/NR2B NMDA channel kinetics and synaptic signalling profiles. J Physiol 563: $345-358$.

Gao XM, Elmer GI, Adams-Huet B, Tamminga CA. 2009. Social memory in mice: disruption with an NMDA antagonist and attenuation with antipsychotic drugs. Pharmacol Biochem Behav 92: 236-242.

Gao C, Gill MB, Tronson NC, Guedea AL, Guzman YF, Huh KH, Corcoran KA, Swanson GT, Radulovic J. 2010. Hippocampal NMDA receptor subunits differentially regulate fear memory formation and neuronal signal propagation. Hippocampus 20: 1072-1082.

Gardoni F, Bellone C, Cattabeni F, Di Luca M. 2001. Protein kinase C activation modulates $\alpha$-calmodulin kinase II binding to NR2A subunit of $\mathrm{N}$-methyl-D-aspartate receptor complex. J Biol Chem 276: $7609-7613$.

Groning J, Hochkirch A. 2008. Reproductive interference between animal species. Q Rev Biol 83: 257-282.

Gupta-Agarwal S, Jarome TJ, Fernandez J, Lubin FD. 2014. NMDA receptorand ERK-dependent histone methylation changes in the lateral amygdala bidirectionally regulate fear memory formation. Learn Mem 21: $351-362$.

Hestrin S. 1992a. Activation and desensitization of glutamate-activated channels mediating fast excitatory synaptic currents in the visual-cortex. Neuron 9: 991-999.

Hestrin S. 1992b. Developmental regulation of NMDA receptor-mediated synaptic currents at a central synapse. Nature 357: 686-689.

Hillman BG, Gupta SC, Stairs DJ, Buonanno A, Dravid SM. 2011. Behavioral analysis of NR2C knockout mouse reveals deficit in acquisition of conditioned fear and working memory. Neurobiol Learn Mem 95: 404-414.

Hlinak Z, Krejci I. 2002. N-methyl-D-aspartate improved social recognition potency in rats. Neurosci Lett 330: 227-230.

Ikeda K, Araki K, Takayama C, Inoue Y, Yagi T, Aizawa S, Mishina M. 1995. Reduced spontaneous activity of mice defective in the $\epsilon 4$ subunit of the NMDA receptor channel. Brain Res Mol Brain Res 33: 61-71.

Ito I, Sakimura K, Mishina M, Sugiyama H. 1996. Age-dependent reduction of hippocampal LTP in mice lacking $N$-methyl-D-aspartate receptor $\epsilon 1$ subunit. Neurosci Lett 203: 69-71.

Jacobs SA, Tsien JZ. 2012. Genetic overexpression of NR2B subunit enhances social recognition memory for different strains and species. PLoS One 7: e36387.

Jacobs SA, Tsien JZ. 2014. Overexpression of the NR2A subunit in the forebrain impairs long-term social recognition and non-social olfactory memory. Genes Brain Behav 13: 376-384.

Jacobs S, Cui Z, Feng R, Wang H, Wang D, Tsien JZ. 2014. Molecular and genetic determinants of the NMDA receptor for superior learning and memory functions. PLoS One 9: e111865.

Kennedy MB. 1997. The postsynaptic density at glutamatergic synapses. Trends Neurosci 20: $264-268$.

Kennedy PR, Bakay RA. 1997. Activity of single action potentials in monkey motor cortex during long-term task learning. Brain Res 760: 251-254.

Kennedy MB, Beale HC, Carlisle HJ, Washburn LR. 2005. Integration of biochemical signalling in spines. Nat Rev Neurosci 6: 423-434.

Kornau HC, Seeburg PH, Kennedy MB. 1997. Interaction of ion channels and receptors with PDZ domain proteins. Curr Opin Neurobiol 7: $368-373$

Kuang H, Lin L, Tsien JZ. 2010. Temporal dynamics of distinct CA1 cell populations during unconscious state induced by ketamine. PLoS One 5: e15209.

Kutsuwada T, Sakimura K, Manabe T, Takayama C, Katakura N, Kushiya E, Natsume R, Watanabe M, Inoue Y, Yagi T, et al. 1996. Impairment of suckling response, trigeminal neuronal pattern formation, and hippocampal LTD in NMDA receptor $\epsilon 2$ subunit mutant mice. Neuron 16: $333-344$

Leinders-Zufall T, Brennan P, Widmayer P, S PC, Maul-Pavicic A, Jager M, Li XH, Breer H, Zufall F, Boehm T. 2004. MHC class I peptides as chemosensory signals in the vomeronasal organ. Science 306: $1033-1037$.

Li F, Tsien JZ. 2009. Memory and the NMDA receptors. N Engl J Med 361: 302-303.

Liu X, Gu QH, Duan K, Li Z. 2014. NMDA receptor-dependent LTD is required for consolidation but not acquisition of fear memory. $J$ Neurosci 34: 8741-8748.

Macbeth AH, Lee HJ, Edds J, Young WS III. 2009. Oxytocin and the oxytocin receptor underlie intrastrain, but not interstrain, social recognition. Genes Brain Behav 8: 558-567.

Matsuo T, Hattori T, Asaba A, Inoue N, Kanomata N, Kikusui T, Kobayakawa R, Kobayakawa K. 2015. Genetic dissection of pheromone processing reveals main olfactory system-mediated social behaviors in mice. Proc Natl Acad Sci 112: E311-E320.

McHugh TJ, Blum KI, Tsien JZ, Tonegawa S, Wilson MA. 1996. Impaired hippocampal representation of space in CA1-specific NMDAR1 knockout mice. Cell 87: 1339-1349.

Mei B, Li F, Gu Y, Cui Z, Tsien JZ. 2011. NMDA receptors are not required for pattern completion during associative memory recall. PLoS One 6: e19326.

Mohrmann R, Kohr G, Hatt H, Sprengel R, Gottmann K. 2002. Deletion of the C-terminal domain of the NR2B subunit alters channel properties and synaptic targeting of $\mathrm{N}$-methyl-D-aspartate receptors in nascent neocortical synapses. J Neurosci Res 68: 265-275.

Monyer H, Sprengel R, Schoepfer R, Herb A, Higuchi M, Lomeli H, Burnashev N, Sakmann B, Seeburg PH. 1992. Heteromeric NMDA receptors: molecular and functional distinction of subtypes. Science 256: $1217-1221$.

Monyer H, Burnashev N, Laurie DJ, Sakmann B, Seeburg PH. 1994. Developmental and regional expression in the rat brain and functional properties of four NMDA receptors. Neuron 12: 529-540.

Murphy JA, Stein IS, Lau CG, Peixoto RT, Aman TK, Kaneko N, Aromolaran K, Saulnier JL, Popescu GK, Sabatini BL, et al. 2014. Phosphorylation of Ser1166 on GluN2B by PKA is critical to synaptic 
NMDA receptor function and $\mathrm{Ca}^{2+}$ signaling in spines. J Neurosci 34: 869-879.

Noack J, Richter K, Laube G, Haghgoo HA, Veh RW, Engelmann M. 2010. Different importance of the volatile and non-volatile fractions of an olfactory signature for individual social recognition in rats versus mice and short-term versus long-term memory. Neurobiol Learn Mem 94: $568-575$.

Okamoto KW, Grether GF. 2013. The evolution of species recognition in competitive and mating contexts: the relative efficacy of alternative mechanisms of character displacement. Ecol Lett 16: 670-678.

Olson IR, McCoy D, Klobusicky E, Ross LA. 2013. Social cognition and the anterior temporal lobes: a review and theoretical framework. Soc Cogn Affect Neurosci 8: 123-133.

Ord TJ, Stamps JA. 2009. Species identity cues in animal communication. Am Nat 174: 585-593.

Philpot BD, Weisberg MP, Ramos MS, Sawtell NB, Tang YP, Tsien JZ, Bear MF. 2001. Effect of transgenic overexpression of NR2B on NMDA receptor function and synaptic plasticity in visual cortex. Neuropharmacology 41: 762-770.

Punnakkal P, Jendritza P, Kohr G. 2012. Influence of the intracellular GluN2 C-terminal domain on NMDA receptor function. Neuropharmacology 62: $1985-1992$.

Rampon C, Jiang CH, Dong H, Tang YP, Lockhart DJ, Schultz PG, Tsien JZ, Hu Y. 2000a. Effects of environmental enrichment on gene expression in the brain. Proc Natl Acad Sci 97: 12880-12884.

Rampon C, Tang YP, Goodhouse J, Shimizu E, Kyin M, Tsien JZ. 2000b. Enrichment induces structural changes and recovery from nonspatial memory deficits in CA1 NMDAR1-knockout mice. Nat Neurosci 3: $238-244$.

Roesler R, Reolon GK, Luft T, Martins MR, Schroder N, Vianna MR, Quevedo J. 2005. NMDA receptors mediate consolidation of contextual memory in the hippocampus after context preexposure. Neurochem Res 30: $1407-1411$.

Rossi P, Sola E, Taglietti V, Borchardt T, Steigerwald F, Utvik JK, Ottersen OP, Köhr G, D'Angelo E. 2002. NMDA receptor 2 (NR2) C-terminal control of NR open probability regulates synaptic transmission and plasticity at a cerebellar synapse. J Neurosci 22: 9687-9697.

Ryan TJ, Kopanitsa MV, Indersmitten T, Nithianantharajah J, Afinowi NO, Pettit C, Stanford LE, Sprengel R, Saksida LM, Bussey TJ, et al. 2013. Evolution of GluN2A/B cytoplasmic domains diversified vertebrate synaptic plasticity and behavior. Nat Neurosci 16: 25-32.

Sakimura K, Kutsuwada T, Ito I, Manabe T, Takayama C, Kushiya E, Yagi T, Aizawa S, Inoue Y, Sugiyama H, et al. 1995. Reduced hippocampal LTP and spatial learning in mice lacking NMDA receptor $\epsilon 1$ subunit. Nature 373: $151-155$.

Sanchez-Andrade G, Kendrick KM. 2009. The main olfactory system and social learning in mammals. Behav Brain Res 200: 323-335.

Santini E, Muller RU, Quirk GJ. 2001. Consolidation of extinction learning involves transfer from NMDA-independent to NMDA-dependent memory. J Neurosci 21: 9009-9017.

Sheng M. 1996. PDZs and receptor/channel clustering: rounding up the latest suspects. Neuron 17: $575-578$.

Sheng M, Cummings J, Roldan LA, Jan YN, Jan LY. 1994. Changing subunit composition of heteromeric NMDA receptors during development of rat cortex. Nature 368: $144-147$.

Shimizu E, Tang YP, Rampon C, Tsien JZ. 2000. NMDA receptor-dependent synaptic reinforcement as a crucial process for memory consolidation. Science 290: $1170-1174$

Sinai L, Mathew R, Roder JC. 2012. Impaired social memories in 129P2 inbred mice are rescued by reduced Csk expression. Genes Brain Behav 11: $559-567$.

Spehr M, Kelliher KR, Li XH, Boehm T, Leinders-Zufall T, Zufall F. 2006. Essential role of the main olfactory system in social recognition of major histocompatibility complex peptide ligands. J Neurosci 26: 1961-1970.

Sprengel R, Suchanek B, Amico C, Brusa R, Burnashev N, Rozov A, Hvalby O, Jensen V, Paulsen O, Andersen P, et al. 1998. Importance of the intracellular domain of NR2 subunits for NMDA receptor function in vivo. Cell 92: 279-289.

Staples LG, Hunt GE, van Nieuwenhuijzen PS, McGregor IS. 2008a. Rats discriminate individual cats by their odor: possible involvement of the accessory olfactory system. Neurosci Biobehav Rev 32: 1209-1217.
Staples LG, McGregor IS, Apfelbach R, Hunt GE. 2008b. Cat odor, but not trimethylthiazoline (fox odor), activates accessory olfactory and defense-related brain regions in rats. Neuroscience 151: 937-947.

Steigerwald F, Schulz TW, Schenker LT, Kennedy MB, Seeburg PH, Köhr G. 2000. C-Terminal truncation of NR2A subunits impairs synaptic but not extrasynaptic localization of NMDA receptors. J Neurosci 20: $4573-4581$.

Szapiro G, Vianna MR, McGaugh JL, Medina JH, Izquierdo I. 2003. The role of NMDA glutamate receptors, PKA, MAPK, and CAMKII in the hippocampus in extinction of conditioned fear. Hippocampus 13: $53-58$.

Tang YP, Shimizu E, Dube GR, Rampon C, Kerchner GA, Zhuo M, Liu G, Tsien JZ. 1999. Genetic enhancement of learning and memory in mice. Nature 401: 63-69.

Tang YP, Wang H, Feng R, Kyin M, Tsien JZ. 2001. Differential effects of enrichment on learning and memory function in NR2B transgenic mice. Neuropharmacology 41: 779-790.

Tang TT, Badger JD II, Roche PA, Roche KW. 2010. Novel approach to probe subunit-specific contributions to $N$-methyl-D-aspartate (NMDA) receptor trafficking reveals a dominant role for NR2B in receptor recycling. J Biol Chem 285: 20975-20981.

Thor DH, Holloway WR. 1982. Social memory of the male laboratory rat. $J$ Comp Physiol Psychol 96: 1000-1006.

Tonegawa S, Tsien JZ, McHugh TJ, Huerta P, Blum KI, Wilson MA. 1996. Hippocampal CA1-region-restricted knockout of NMDAR1 gene disrupts synaptic plasticity, place fields, and spatial learning. Cold Spring Harb Symp Quant Biol 61: 225-238.

Tsien JZ, Huerta PT, Tonegawa S. 1996. The essential role of hippocampal CA1 NMDA receptor-dependent synaptic plasticity in spatial memory. Cell 87: 1327-1338.

van der Kooij MA, Sandi C. 2012. Social memories in rodents: methods, mechanisms and modulation by stress. Neurosci Biobehav Rev 36: $1763-1772$.

van der Staay FJ, Rutten K, Erb C, Blokland A. 2011. Effects of the cognition impairer MK-801 on learning and memory in mice and rats. Behav Brain Res 220: $215-229$.

Vyklicky V, Korinek M, Smejkalova T, Balik A, Krausova B, Kaniakova M, Lichnerova K, Cerny J, Krusek J, Dittert I, et al. 2014. Structure, function, and pharmacology of NMDA receptor channels. Physiol Res 63 Suppl 1: S191-S203.

Walker DL, Davis M. 2008. Amygdala infusions of an NR2B-selective or an NR2A-preferring NMDA receptor antagonist differentially influence fear conditioning and expression in the fear-potentiated startle test. Learn Mem 15: 67-74.

Wang D, Cui Z, Zeng Q, Kuang H, Wang LP, Tsien JZ, Cao X. 2009. Genetic enhancement of memory and long-term potentiation but not CA1 long-term depression in NR2B transgenic rats. PLoS One 4: e7486.

White TL, Youngentob SL. 2004. The effect of NMDA-NR2B receptor subunit over-expression on olfactory memory task performance in the mouse. Brain Res 1021: 1-7.

Winslow JT, Camacho F. 1995. Cholinergic modulation of a decrement in social investigation following repeated contacts between mice. Psychopharmacology (Berl) 121: 164-172.

Wu CL, Xia S, Fu TF, Wang H, Chen YH, Leong D, Chiang AS, Tully T. 2007. Specific requirement of NMDA receptors for long-term memory consolidation in Drosophila ellipsoid body. Nat Neurosci 10: $1578-1586$.

Wyllie DJ, Livesey MR, Hardingham GE. 2013. Influence of GluN2 subunit identity on NMDA receptor function. Neuropharmacology 74: 4-17.

Zhang H, Chen G, Kuang H, Tsien JZ. 2013. Mapping and deciphering neural codes of NMDA receptor-dependent fear memory engrams in the hippocampus. PLoS One 8: e79454.

Zimmerman JM, Maren S. 2010. NMDA receptor antagonism in the basolateral but not central amygdala blocks the extinction of Pavlovian fear conditioning in rats. Eur J Neurosci 31: 1664-1670.

Received March 3, 2015; accepted in revised form June 9, 2015. 


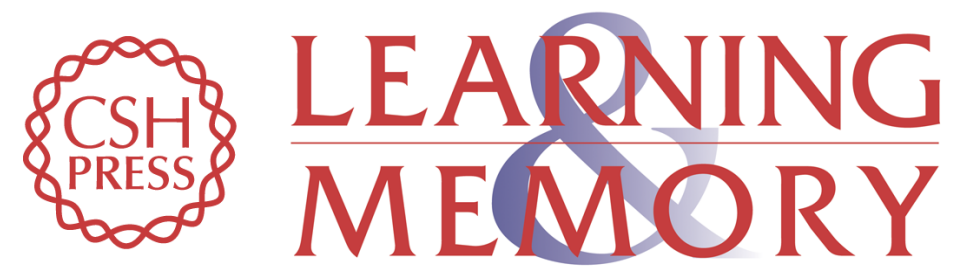

\section{Importance of the GluN2B carboxy-terminal domain for enhancement of social memories}

Stephanie Jacobs, Wei Wei, Deheng Wang, et al.

Learn. Mem. 2015, 22:

Access the most recent version at doi:10.1101/Im.038521.115

\begin{aligned} & \hline References $\begin{array}{l}\text { This article cites } 88 \text { articles, } 22 \text { of which can be accessed free at: } \\ \text { http://learnmem.cshlp.org/content/22/8/401.full.html\#ref-list-1 }\end{array} \\ & \begin{array}{r}\text { Creative } \\ \text { Commons } \\ \text { License }\end{array} \begin{array}{l}\text { This article is distributed exclusively by Cold Spring Harbor Laboratory Press for the } \\ \text { first } 12 \text { months after the full-issue publication date (see } \\ \text { http://learnmem.cshlp.org/site/misc/terms.xhtml). After } 12 \text { months, it is available under } \\ \text { a Creative Commons License (Attribution-NonCommercial } 4.0 \text { International), as } \\ \text { described at http://creativecommons.org/licenses/by-nc/4.0/. }\end{array} \\ & \begin{array}{c}\text { Receive free email alerts when new articles cite this article - sign up in the box at the } \\ \text { top right corner of the article or click here. }\end{array} \\ & \begin{array}{c}\text { Service } \\ \text { terting }\end{array}\end{aligned}$ 